\title{
Effect of growth hormone administration on IGF binding protein-3 mRNA levels in porcine tissues
}

\section{Dunaiski ${ }^{1}$, F R Dunshea ${ }^{2}$, P E Walton ${ }^{3}$ and C Goddard ${ }^{3}$}

\author{
${ }^{1}$ Co-operative Research Centre for Tissue Growth and Repair, Child Health Research Institute, \\ 72 King William Road, North Adelaide, South Australia 5006, Australia \\ ${ }^{2}$ Victorian Institute of Animal Science, Werribee, Victoria 3030, Australia \\ ${ }^{3}$ CSIRO Human Nutrition, PO Box 10065 Gouger Street, Adelaide, South Australia 5000, Australia \\ (Requests for offprints should be addressed to V Dunaiski) \\ (P E Walton is currently at Diagnostic Systems Laboratories Inc., 445 Medical Center Boulevard, \\ Webster, Texas 77598-4217, USA)
}

\begin{abstract}
The effect of short-term GH treatment on steady-state insulin-like growth factor binding protein-3 (IGFBP-3) mRNA levels in liver, kidney, longissimus dorsi muscle, stomach and jejunum was examined in pigs. Ten female crossbred pigs were allocated to either saline or $\mathrm{GH}$ $(70 \mu \mathrm{g} / \mathrm{kg} /$ day) treatment by subcutaneous injection for 4 days. They were allowed to feed ad libitum, and were weighed daily. At the end of the treatment period, the pigs were slaughtered and samples of liver, kidney, skeletal muscle, stomach and jejunum were collected and total RNA was extracted. Steady-state levels of IGFBP-3 mRNA were quantified by RNase protection assay and were compared with the level of IGF-I class 1 and class 2
\end{abstract}

transcripts. IGFBP-3 mRNA increased in response to $\mathrm{GH}$ in both liver and kidney, but not in the other tissues sampled. Hepatic IGF-I mRNA responded to short-term GH treatment with a fourfold increase in IGF-I class $1 \mathrm{mRNA}$ and an eightfold increase in IGF-I class 2 mRNA, which was liver specific. IGF-I class $1 \mathrm{mRNA}$ was not responsive to GH treatment in other tissues. The short-term nature of this treatment suggests that the increase in hepatic IGFBP-3 and IGF-I transcripts is a relatively early response to treatment with $\mathrm{GH}$, and that the increase in plasma concentrations of IGFBP-3 in response to GH are derived from the liver, the kidney, or both.

Fournal of Molecular Endocrinology (1999) 22, 261-272

\section{INTRODUCTION}

The developing pig is particularly sensitive to treatment with growth hormone (GH), which increases the average daily weight gain (Etherton et al. 1987), enhances protein accretion and reduces fat deposition (Campbell et al. 1989). A number of components of the somatotrophic axis are involved in the response to $\mathrm{GH}$, but the way in which each is regulated to provide a co-ordinated response in the pig has not been fully elucidated. Many of the growth promoting actions of $\mathrm{GH}$ are mediated via insulin-like growth factor-I (IGF-I), and it is well established that $\mathrm{GH}$ treatment increases porcine plasma concentrations of IGF-I (Owens et al. 1990, Coleman \& Etherton 1991). The primary source of the increased plasma IGF-I concentration is likely to be the liver, although many other tissues are able to produce IGF-I resulting in autocrine or paracrine, in addition to endocrine, effects of the peptide. It is not known what contribution the production of IGF-I in each tissue makes to the overall plasma IGF-I pool.

Growth hormone and nutritional status are the major regulators of porcine IGF-I gene expression (Brameld et al. 1996). Different leader exons (exons 1 and 2) for IGF-I are alternatively spliced to exon 3, which encodes part of the mature IGF-I protein. Initiation of transcription at multiple dispersed start sites upstream of exon 1 or 2 yields two distinct IGF-I mRNAs, class 1 and class 2, which produce different precursor peptides (Weller et al. 1993). In the liver, expression of hepatic IGF-I class $2 \mathrm{mRNA}$ is more sensitive to changes that affect optimal growth than is IGF-I class 1 mRNA. IGF-I class 2 mRNA expression is closely related to circulating IGF-I concentrations and growth rates when they are altered by energy 
manipulation (Weller et al. 1994). By using sensitive, exon-specific ribonuclease (RNase) protection assays, these authors dissected the tissue-specific expression of IGF-I class 1 and class 2 transcripts in response to $\mathrm{GH}$ administration in addition to changes in dietary protein intake. Increased plasma IGF-I concentrations were accompanied by increased hepatic IGF-I mRNA expression in response to GH. Increased transcription rates were derived from both exons, although exon 2 expression was found only in the liver of GH-treated pigs. In muscle, the response of IGF-I class 1 transcripts to $\mathrm{GH}$ administration was dependent on muscle fibre type. In adipose tissue, there was a significant effect of both $\mathrm{GH}$ and dietary manipulation on the level of IGF-I class $1 \mathrm{mRNA}$ expression and an interaction between the treatments (Brameld et al. 1996). These studies confirmed and extended the work by Coleman et al. (1994) suggesting that GH treatment increased IGF-I expression in the liver and adipose tissue, but not in skeletal muscle, of growing pigs.

Insulin-like growth factor binding protein-3 (IGFBP-3), associated with the acid-labile subunit, is the primary carrier of IGF peptides in the circulation. The rat has been the most extensively studied species (Shimasaki et al. 1989). The wide tissue distribution of IGFBP-3 suggests that it has an important role in the autocrine/paracrine action of IGF-I, although no correlation has been observed between IGF-I and IGFBP-3 mRNA expression in different tissues (Albiston \& Herington 1992). In the pig, plasma IGF-I and IGFBP-3 levels are increased in GH-treated animals (Dunaiski et al. 1997), but regulation of IGFBP-3 mRNA expression by GH has not been studied. In the rat, liver IGFBP-3 mRNA expression is regulated by $\mathrm{GH}$, but appears to be less sensitive than IGF-I mRNA to circulating GH concentrations (Domenè et al. 1993). The current study was designed to compare the effect of short-term GH treatment on the expression of IGFBP-3 mRNA with IGF-I class 1 and class 2 mRNA levels in liver, kidney, skeletal muscle (longissimus dorsi), stomach and small intestine of the growing pig which is more sensitive than the rat to treatment with exogenous GH (Walton et al. 1995).

\section{MATERIALS AND METHODS}

\section{Animals and procedures}

Ten female crossbred pigs $(55 \mathrm{~kg}$ ) were randomly allocated to one of two treatment groups. Pigs were individually penned and were fed $110 \mathrm{~g} / \mathrm{kg}$ body weight per day divided into three meals given at 0800,1200 and $1600 \mathrm{~h}$. The diet consisted of $20 \cdot 4 \%$ total crude protein, $14.5 \mathrm{MJ} / \mathrm{kg}$ digested energy and $1 \cdot 28 \%$ lysine. Animals were weighed daily during the course of the experiment. Animals received a once-daily s.c. injection of either saline or porcine GH $(70 \mu \mathrm{g} / \mathrm{kg} /$ day) (Bresatec Pty Ltd, Adelaide, Australia) for 4 days. On the last day of treatment, the daily dose was given as two injections $12 \mathrm{~h}$ apart. One hour after the last injection, the animals were killed and samples were taken from the left anterior lobe of the liver, the left kidney, including sections of the medulla and cortex, skeletal muscle from a point $6.5 \mathrm{~cm}$ from the midline over the last rib (longissimus dorsi), the small intestine (jejunum) and the posterior stomach. Tissue samples were snap frozen in liquid nitrogen and stored at $-80{ }^{\circ} \mathrm{C}$ until they were required for analysis.

\section{Isolation of RNA}

Approximately $2 \mathrm{~g}$ frozen tissue were homogenised in $1 \mathrm{ml} \mathrm{RNAzol} \mathrm{B}$ (Tel-Test Inc., Friendswood, Texas, USA). An aliquot of $2 \mathrm{ml} \mathrm{RNAzol} \mathrm{B}$ and $0.4 \mathrm{ml}$ chloroform was added to the homogenised sample and extraction of total RNA was then performed according to the manufacturer's instructions. The final RNA pellet was washed with $0.5 \mathrm{ml} \mathrm{LiCl}(4 \mathrm{~mol} / \mathrm{l})$ followed by $0.5 \mathrm{ml}$ ethanol $(70 \% \mathrm{v} / \mathrm{v})$, before the RNA was resuspended in $100 \mu \mathrm{l}$ diethyl pyrocarbonate (DEP-C)-treated water. RNA was quantified by measuring the absorbance at $260 \mathrm{~nm}$.

\section{Generation of radioactive riboprobes and markers}

DNA molecular weight markers BMVII (Boehringer Mannheim Biochemicals, Indianapolis, Indiana, USA) were end labelled using a DNA 5' end labelling kit (Boehringer Mannheim Biochemicals). High specific activity riboprobes were generated using a T7/T3 transcription kit (Promega Corporation, Madison, WI, USA) with $100 \mathrm{ng}$ linearised template DNA and 10 units RNA polymerase.

Plasmids pRP1 and pRP2 were kindly donated by Dr Stewart Gilmour (University of Auckland) and were used to generate antisense riboprobes for the detection of porcine IGF-I class 1 and class 2 mRNA as previously described (Weller et al. 1993). Briefly, pRP1 and pRP2 plasmids were linearised with HindIII and transcribed with T7 RNA polymerase in the presence of $\left[\alpha-{ }^{32} \mathrm{P}\right] \mathrm{UTP}$ (Bresatec Pty Ltd). 

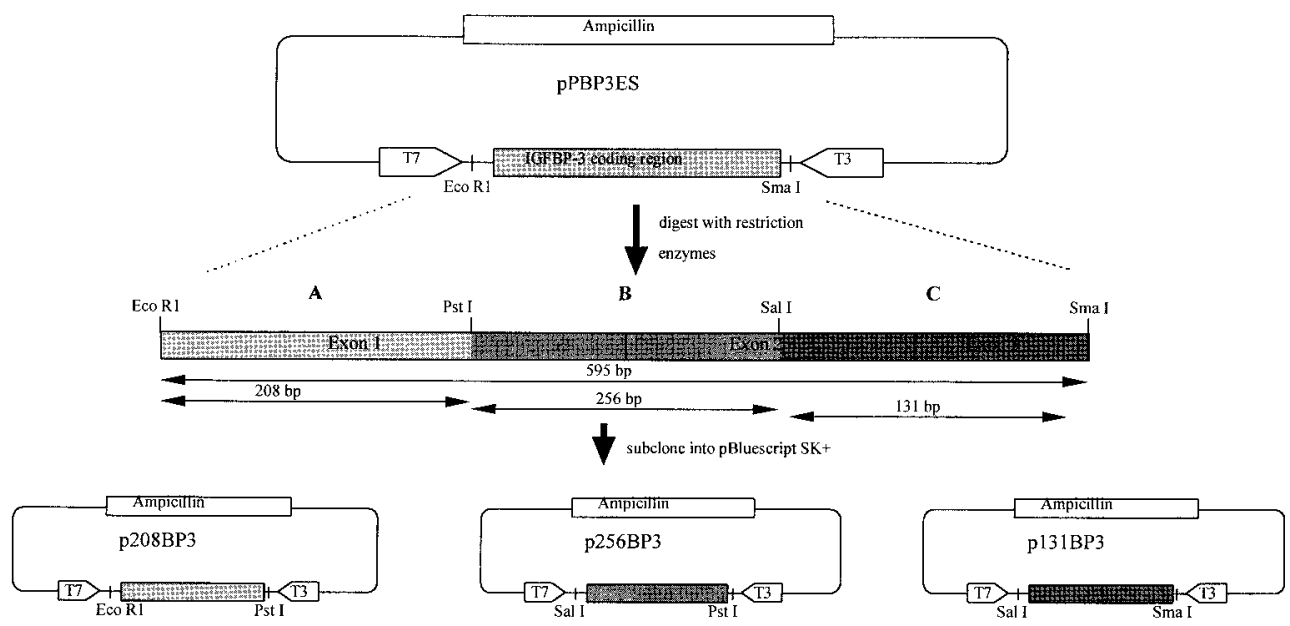

FIGURE 1. Subcloning of IGFBP-3. Three separate restriction digests were carried out using pPBP3ES. To yield a fragment containing only exon 1 pPBP3ES was digested with EcoRI and PstI (A); to yield a fragment containing the 3' end of exon 1 and the 5' end of exon 2, pPBP3ES was digested with PstI and SalI (B); and to yield a fragment containing the remainder of exon 2 and the $5^{\prime}$ end of exon 3, pPBP3ES was digested with SalI and SmaI (C). These digests generated fragments that were $208 \mathrm{bp}, 256 \mathrm{bp}$ and $131 \mathrm{bp}$ in length respectively. These fragments were isolated as described in the text and subcloned into pBluescript II SK+.

For detection of IGFBP-3 mRNA, riboprobes were generated from the plasmid pPBP3ES (kindly donated by Dr Shunichi Shimasaki, Whittier Institute, La Jolla, CA, USA; Shimasaki et al. 1990). The strategy for developing the probes is outlined in Fig. 1. Plasmid pPBP3ES contained a 595-base pair (bp) fragment encoding the first three exons of porcine IGFBP-3 subcloned into the EcoRI/SmaI site of the multiple cloning region of pBluescript II SK ${ }^{+}$. Analysis of the DNA sequence revealed several unique restriction sites suitable for subcloning. The plasmid pPBP3ES was digested with EcoRI and PstI, PstI and SalI, or SalI and SmaI to yield three separate fragments encoding exon 1, part of exons 1 and 2, or part of exons 2 and 3 of porcine IGFBP-3. These fragments were isolated from agarose gels and ligated unidirectionally into the multiple cloning site of pBluescript II $\mathrm{SK}^{+}$. The ligation mixes were transformed into competent $\mathrm{DH} 5 \alpha$ bacteria and plated onto agar plates containing $100 \mu \mathrm{g} / \mathrm{ml}$ ampicillin. After incubation at $37^{\circ} \mathrm{C}$ overnight, resistant colonies were selected and plasmid DNA was prepared. Successful ligation of the IGFBP-3 fragments into pBluescript II $\mathrm{SK}^{+}$was verified by digestion with the appropriate restriction enzymes and electrophoresis on $1 \%$ agarose gels. Each sequence was verified using the dideoxy chain termination method using a kit according to the manufacturer's instructions (Pharmacia-LKB Biotech, Uppsala, Sweden).
To generate antisense probes for detection of porcine IGFBP-3 mRNA, $10 \mu \mathrm{g}$ pPBP3ES, p256BP3, p208BP3 or p131BP3 were linearised by overnight digestion with 10 units EcoRI, SalI, PstI and SalI respectively. Completion of digestion was visualised on ethidium bromide-stained $1 \%$ agarose gels and the linearised plasmid DNA purified by phenol-chloroform extraction and precipitation with $2.5 \mathrm{vol}$ ethanol in the presence of $0.3 \mathrm{M}$ sodium acetate $\mathrm{pH} 5 \cdot 2$. The DNA template was resuspended in buffer at a concentration of $100 \mathrm{ng} / \mu \mathrm{l}$. Riboprobes were generated using a T7/T3 transcription kit (Promega Corporation). The transcription reaction was initiated by adding, in order: $2 \mu \mathrm{l} 5 \times$ transcription buffer (200 mM Tris-HCl, pH 7.5, $30 \mathrm{mM} \mathrm{MgCl}_{2}$, $10 \mathrm{mM}$ spermidine, $50 \mathrm{mM} \mathrm{NaCl}$ ); $1 \mu \mathrm{l} 100 \mathrm{mM}$ dithiothreitol; $0.5 \mu \mathrm{l}$ RNasin; $2 \mu \mathrm{l}$ ATP, CTP, GTP $\operatorname{mix}(7.5 \mathrm{mM}$ each); $1.2 \mu \mathrm{l} 100 \mu \mathrm{M}$ UTP; $0.5 \mu \mathrm{l}$ linearised template DNA; $25 \mu \mathrm{Ci}[\alpha-$ $\left.{ }^{32} \mathrm{P}\right] \mathrm{U}$ TP and 10 units T3 RNA polymerase; it was then incubated at $37^{\circ} \mathrm{C}$ for $60 \mathrm{~min}$. The DNA template was degraded by the addition of 1 unit RNase free DNase and incubation at $37^{\circ} \mathrm{C}$ for $15 \mathrm{~min}$. To the reaction was added $80 \mu \mathrm{l}$ DEP-C $\mathrm{H}_{2} \mathrm{O}$ and $42 \mu$ phenol-chloroform-iosamyl alcohol $(25: 24: 1)$, followed by thorough mixing and centrifugation at $12500 \boldsymbol{g}$ for $5 \mathrm{~min}$. The upper aqueous phase $(90 \mu \mathrm{l})$ was removed to a fresh tube and the riboprobe precipitated by the addition of $10 \mu 110$ mg/ml tRNA (Sigma, St Louis, Missouri, 
USA), $4 \mu \mathrm{l} 5 \mathrm{M} \mathrm{NaCl}$ and $250 \mu \mathrm{l}$ ethanol and centrifuged at $12500 \mathrm{~g}$ for $15 \mathrm{~min}$. The RNA pellet was washed with $500 \mu \mathrm{l} 70 \%$ ethanol and resuspended in $40 \mu \mathrm{l}$ DEP-C $\mathrm{H}_{2} \mathrm{O}$. To determine percentage incorporation of the radioactive nucleotide, $1 \mu \mathrm{l}$ riboprobe mix was aliquoted into $2 \mathrm{ml}$ scintillant (Beckmann, Fullerton, California, USA) immediately after the completion of the transcription reaction and after the RNA pellet had been precipitated with ethanol and resuspended in DEP-C water. Radioactivity was measured using a $\beta$ counter and the activity of the probe adjusted to $5 \times 10^{5}$ c.p.m. $/ \mu$ l.

The plasmid pT7 RNA 18S (Amnion Inc., Austin, Texas, USA) was used to generate low specific activity riboprobes for detection of $18 \mathrm{~S}$ ribosomal RNA.

\section{Ribonuclease protection assays}

RNase protection assays were carried out as described (Saunders et al. 1991). For detection of IGF-I class 1 , class 2 and IGFBP- 3 mRNA, $50 \mu \mathrm{g}$ total RNA was added to each hybridisation reaction. For detection of $18 \mathrm{~S}$ ribosomal RNA, $10 \mu \mathrm{g}$ total RNA was used to ensure that quantitation was within the linear range of the assay. Each individual sample was analysed in duplicate. Hybridisation was carried out at $45^{\circ} \mathrm{C}$ overnight. RNase digestion was performed at $37^{\circ} \mathrm{C}$ for $1 \mathrm{~h}$, except for $\mathrm{pRP} 1$, with which digestion was carried out at room temperature.

\section{Statistical analysis}

All data were analysed using SigmaStat statistical software version $1 \cdot 0$ (Jandel Scientific Software, CA, USA). Average daily weight gain and feed: gain ratio were analysed using Student's $t$-test. Gels were developed using a phosphorimager (Model No. 425E, Molecular Dynamics, CA, USA) and quantified by measuring the intensities (integrated volumes) of each band using Image Quant version $3 \cdot 2$ software (Molecular Dynamics). The intensities of protected fragments corresponding to IGF-I class 1, class 2 and IGFBP-3 mRNA were normalised and expressed as a percentage of the corresponding intensities for $18 \mathrm{~S}$ ribosomal RNA protected fragments. To avoid interassay variation, all samples from the same tissue type were analysed on one gel. Data were analysed for statistically significant differences using Student's $t$-test and are expressed as the mean \pm S.E.M. with $n=5$. It should be noted that values expressed as a percentage of control relate only to each individual
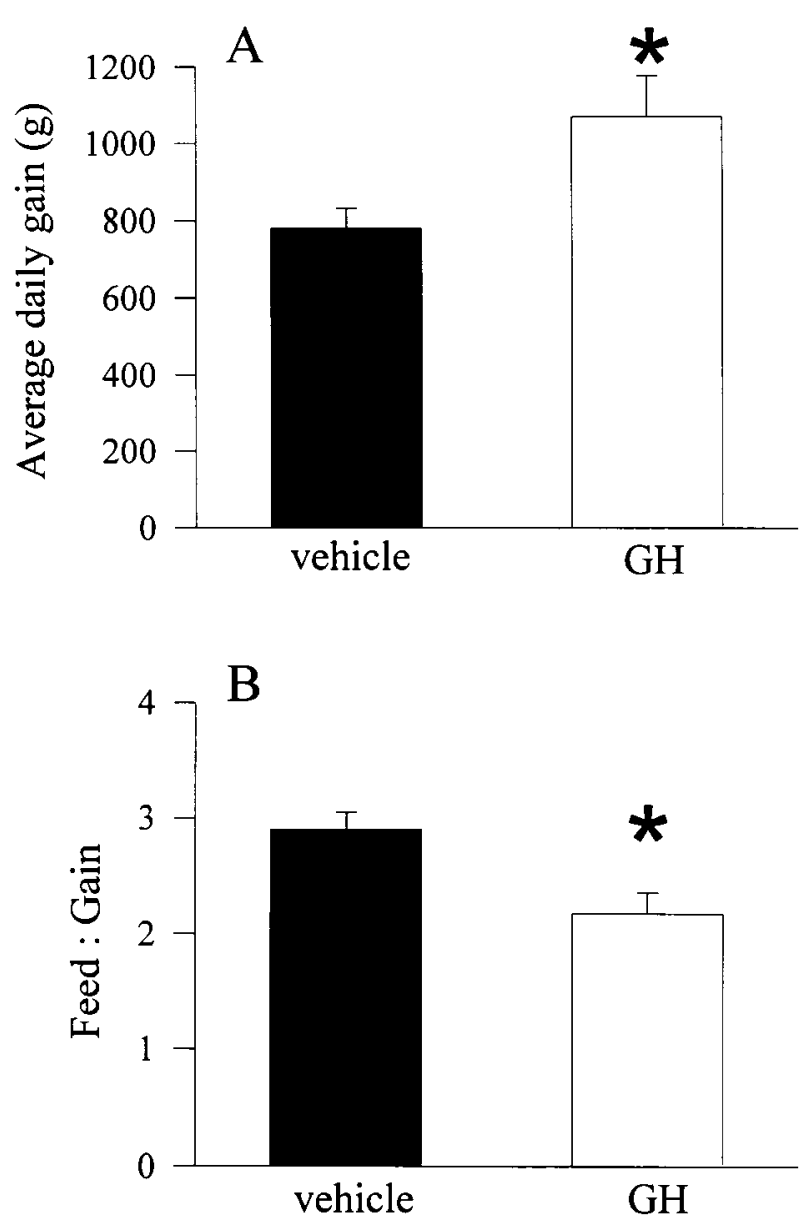

FIGURE 2. Effect of $\mathrm{GH}$ treatment $(70 \mu \mathrm{g} / \mathrm{kg} /$ day $)$ on (A) average daily weight gain and (B) feed : gain ratio over 4 days of treatment. Data were analysed using Student's $t$-test and values are expressed as the mean \pm S.E.M. $(n=5)$. * Significantly different from the saline group $(P<0 \cdot 05)$.

gel and comparison between them should not be made.

\section{RESULTS}

Administration of $\mathrm{GH}$ for 4 days significantly increased the average daily weight gain and decreased feed : gain ratio (Fig. 2).

\section{IGFBP-3 detection}

An antisense RNA probe complementary to the first three exons of porcine IGFBP-3 mRNA was generated from pPBP3ES. This riboprobe was used in an RNase protection assay and hybridised to 


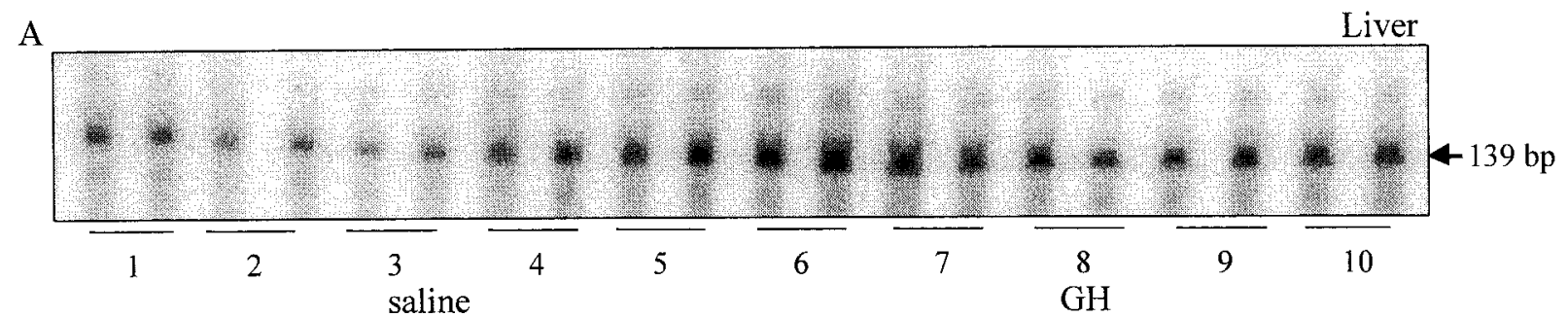

B

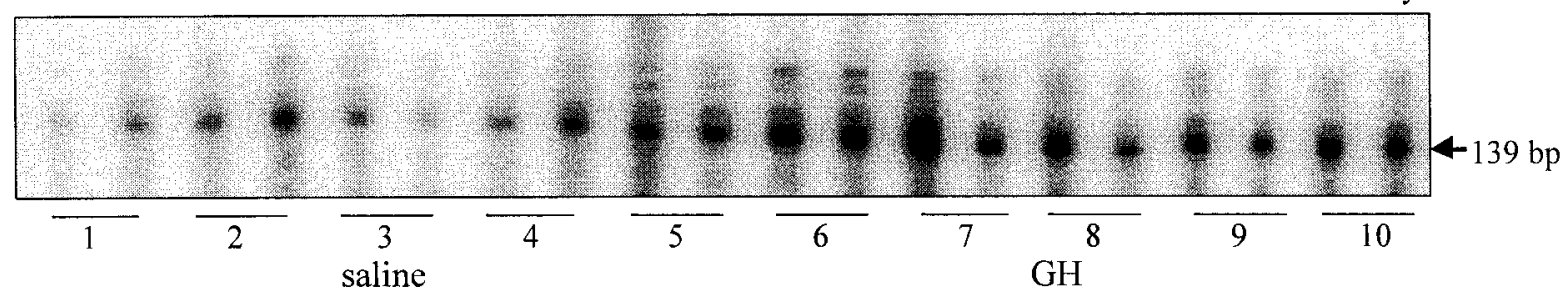

$\mathrm{C}$

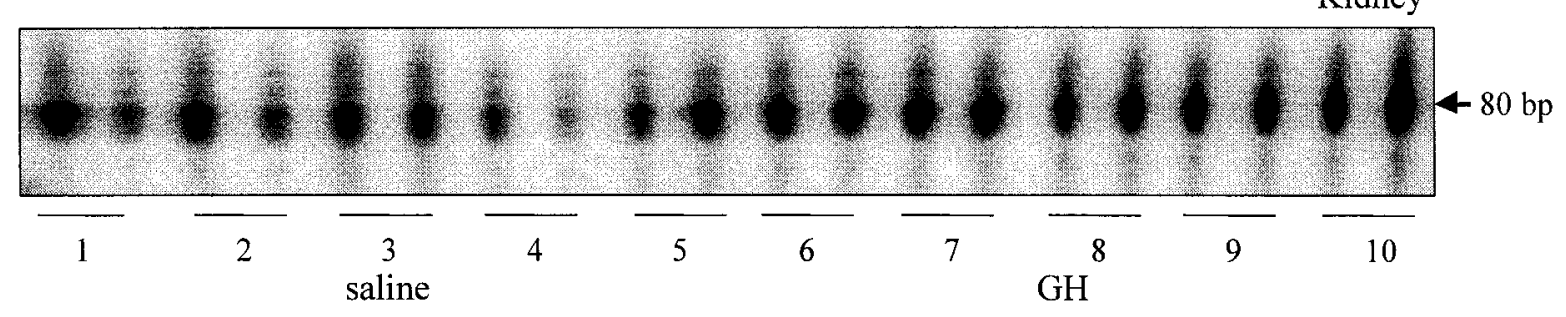

$\mathrm{D}$

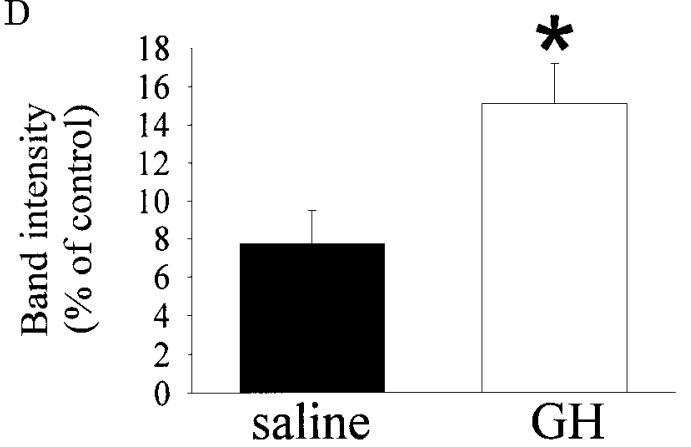

$\mathrm{E}$

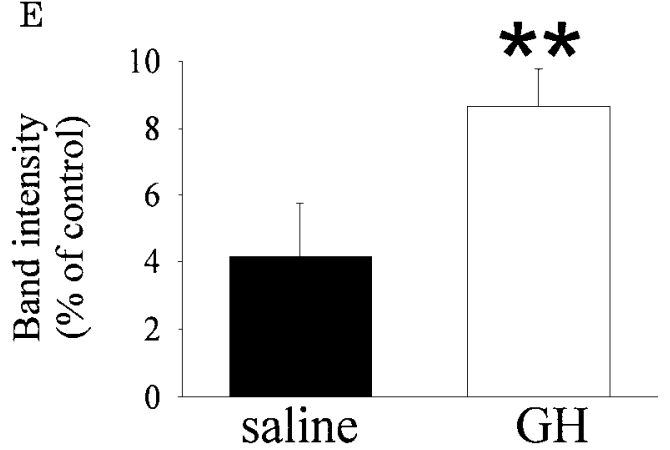

FIGURE 3. Analysis of liver and kidney IGFBP-3 mRNA expression from pigs treated with GH. (A)

Autoradiograph of RNase protection assay using an IGFBP-3 probe hybridised with $50 \mu \mathrm{g}$ total liver RNA from vehicle- (samples 1-5) or GH- (samples 6-10) treated pigs. Each sample was analysed in duplicate. The band at $139 \mathrm{bp}$ represents protection of IGFBP-3 mRNA. (B) Autoradiograph of RNase protection assay using a IGFBP-3 probe hybridised with $50 \mu \mathrm{g}$ total kidney RNA from saline- (samples 1-5) or GH- (samples 6-10) treated pigs. (C) Autoradiograph of RNase protection assay using a ribosomal 18S RNA probe hybridised with $10 \mu \mathrm{g}$ total kidney RNA from vehicle- (samples 1-5) or GH- (samples 6-10) treated pigs. Each sample was analysed in duplicate. The band at $80 \mathrm{bp}$ is derived from protection of ribosomal 18S RNA and is used to control for variations in RNA quantitation. The corresponding RNase protection assay representing expression of $18 \mathrm{~S} \mathrm{RNA}$ in porcine liver is shown in Fig. 5C. Graphical representations of liver IGFBP-3 (D) and kidney IGFBP-3 (E) mRNA levels are shown. Band intensities were quantified using Image Quant software and are expressed as a percentage of the intensity obtained from hybridising the same RNA samples with an 18S RNA probe. Results are expressed as the mean \pm S.E.M. $(n=5)$. Significant differences from the vehicle group: ${ }^{*} P<0 \cdot 03, * * P<0 \cdot 05$. 
A
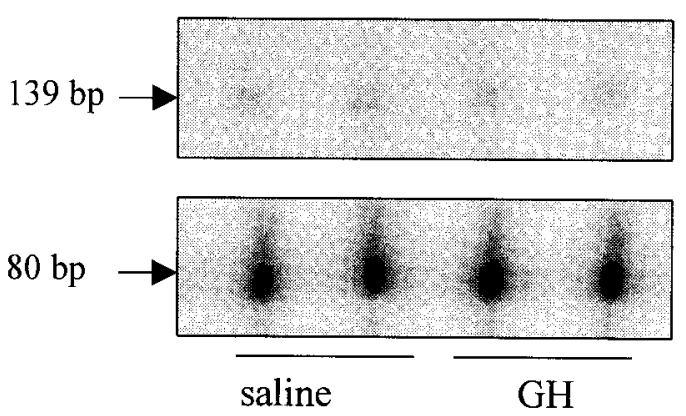

$\mathrm{C}$
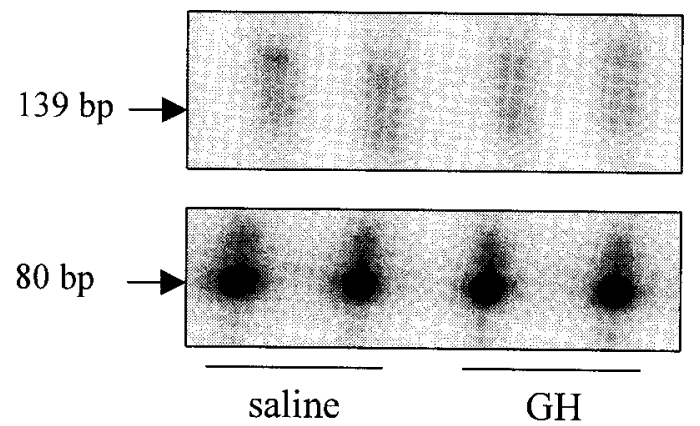

$\mathrm{E}$
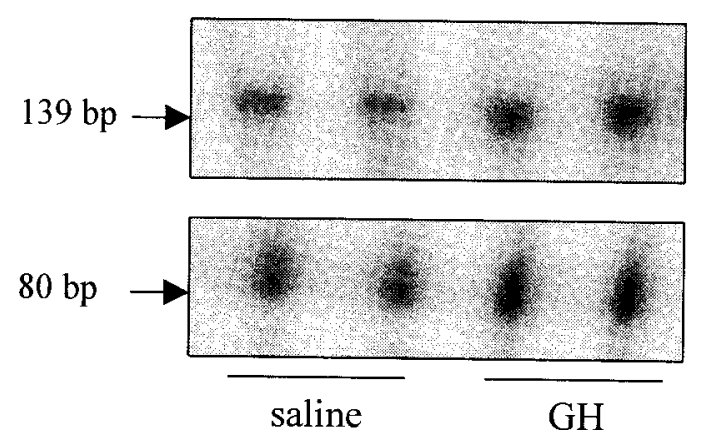

B

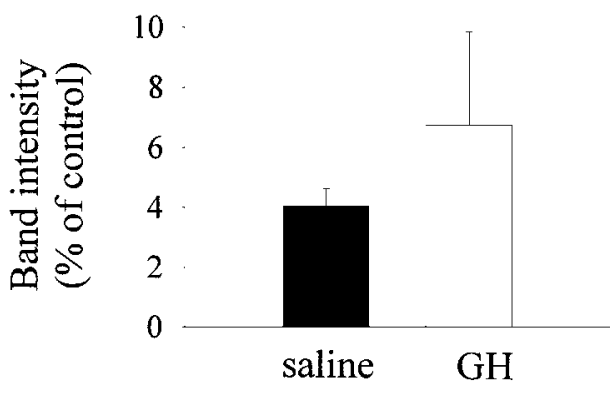

D

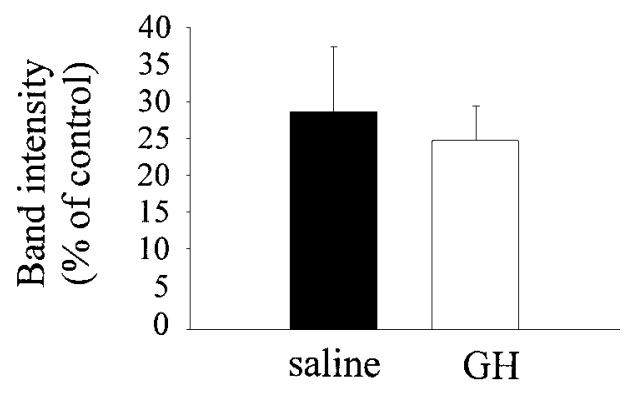

$\mathrm{F}$

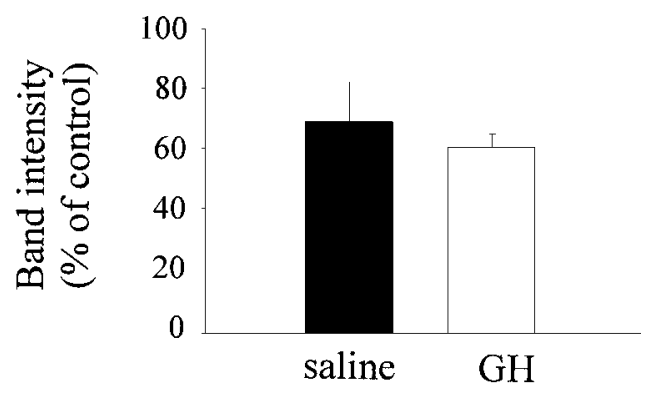

FIGURE 4. Representative autoradiographs of RNase protection assays for IGFBP-3 mRNA expression in muscle (A), stomach (C) and jejenum (E) of saline- and GH-treated pigs. Graphical representations of muscle (B), stomach (D) and jejenum (F) mRNA are also shown. Band intensities were quantified using Image Quant software and are expressed as a percentage of the intensity obtained from hybridising the same RNA samples with an 18S RNA probe. Results are expressed as the mean \pm S.E.M. $(n=5)$.

porcine liver RNA. The results revealed that, although a 665-nucleotide riboprobe of the expected size was generated, no protected fragments were detected at the expected size of 595 bases, although fragments were identified at approximately 250 and 238 bases (data not shown). Investigation of the DNA sequence revealed a region rich in $\mathrm{G}$ and $\mathrm{C}$ residues, and generation of the two protected 

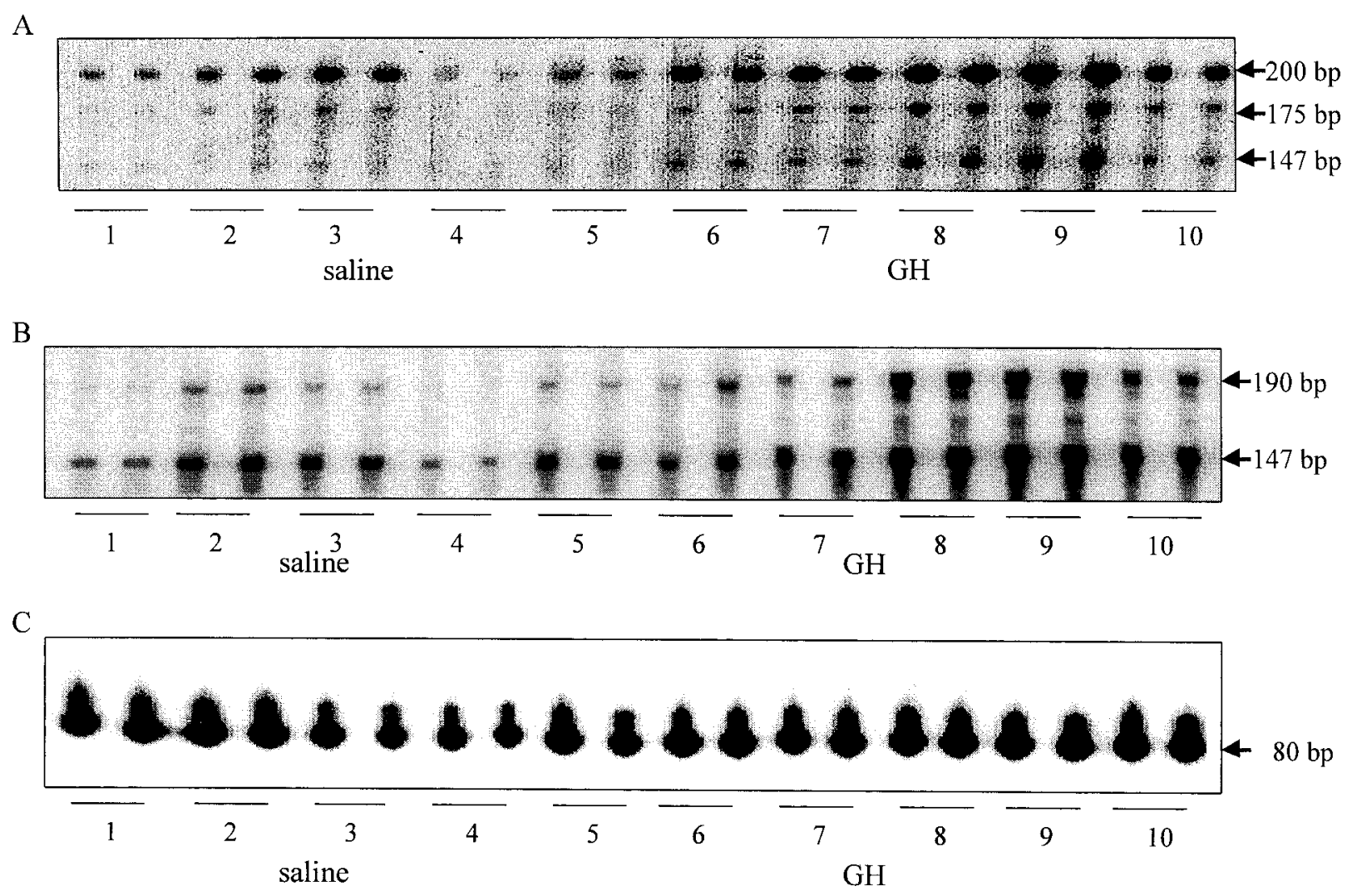

D

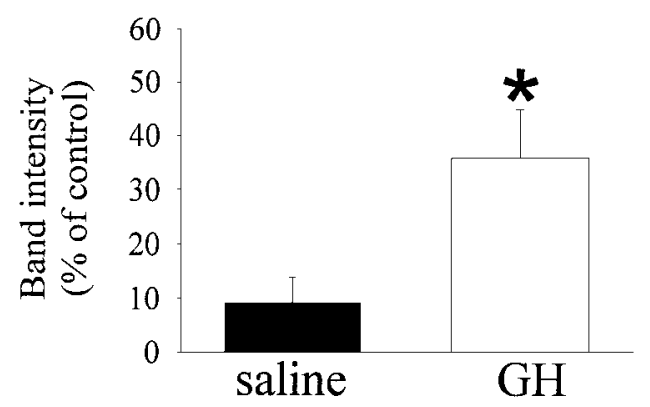

$\mathrm{E}$

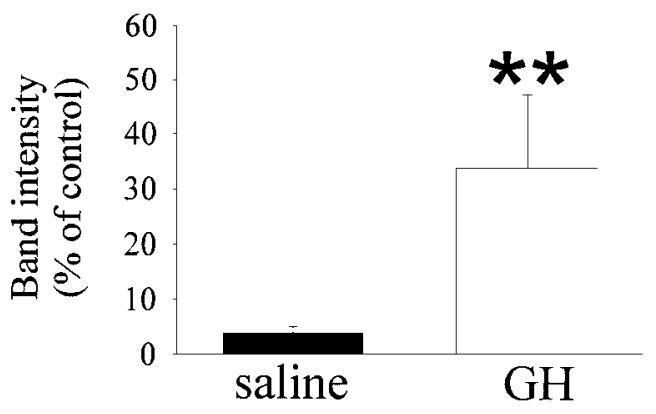

FIGURE 5. Analysis of hepatic IGF-I class 1 and class $2 \mathrm{mRNA}$ expression in pigs treated with GH. (A) Autoradiograph of RNase protection assay using a IGF-I class 1 probe hybridised with $50 \mu \mathrm{g}$ total liver RNA from saline- (samples 1-5) or GH- (samples 6-10) treated pigs. Each sample was analysed in duplicate. The major band at $200 \mathrm{bp}$ results from the protection of exon 1-3 class 1 IGF-I mRNA species. The band at $175 \mathrm{bp}$ is a result of RNase sensitivity under these assay conditions (Weller et al. 1993). The band at $147 \mathrm{bp}$ is derived from protection of mRNAs comprising exon 3 alone and represents all transcripts other than class 1. (B) Autoradiograph of RNase protection assay using a IGF-I class 2 probe hybridised with $50 \mu \mathrm{g}$ total RNA from saline- (samples 1-5) or GH(samples 6-10) treated pigs. Each sample was analysed in duplicate. The band at $190 \mathrm{bp}$ represents protection of exon 2-3 class 2 IGF-I mRNA species. The 147-bp protected fragment is also evident using this riboprobe.

(C) Autoradiograph of RNase protection assay using a ribosomal 18S RNA probe hybridised with $10 \mu \mathrm{g}$ total liver RNA from saline- (samples 1-5) or GH- (samples 6-10) treated pigs. Each sample was analysed in duplicate. The band at $80 \mathrm{bp}$ is derived from protection of ribosomal 18S RNA and is a control for variations in RNA quantitation. Graphical representation of IGF-I class 1 (D) and class 2 (E) liver mRNA levels are also shown. Band intensities were quantified using Image Quant software and are expressed as a percentage of the intensity obtained from hybridising the same RNA samples with an 18S RNA probe. Results are expressed as the mean \pm s.E.M. $(n=5)$. Significant differences from the saline group: $* P<0 \cdot 05$, ** $P<0 \cdot 01$. 
A

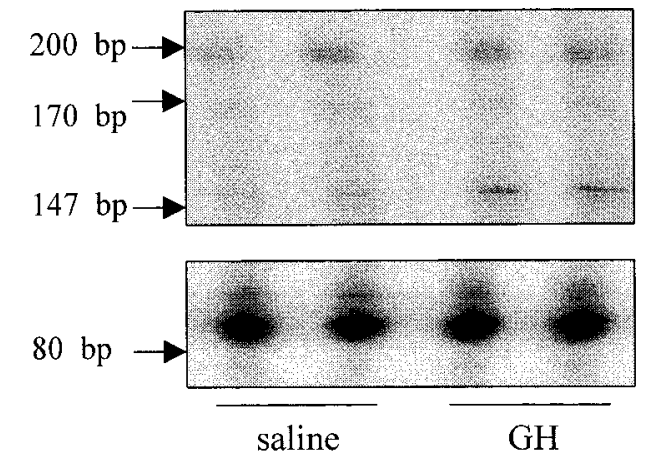

C
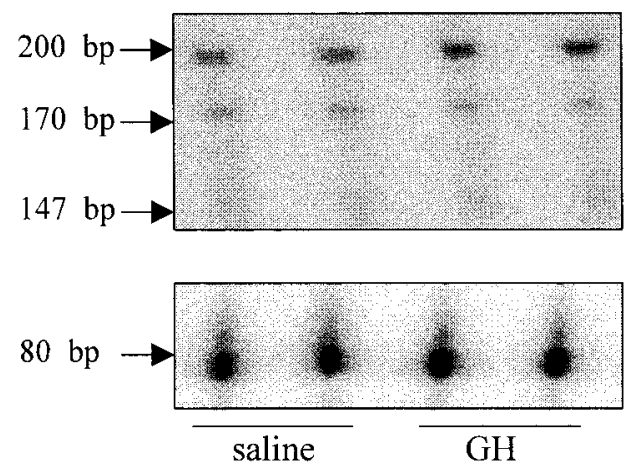

E
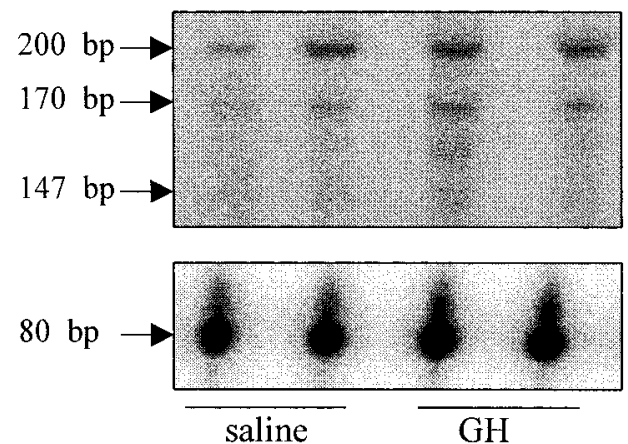

G
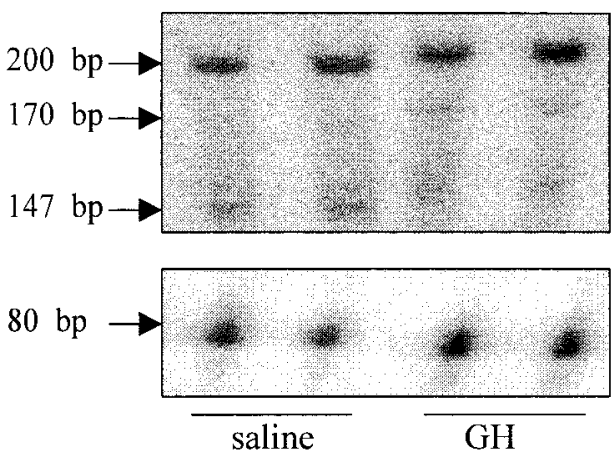

B

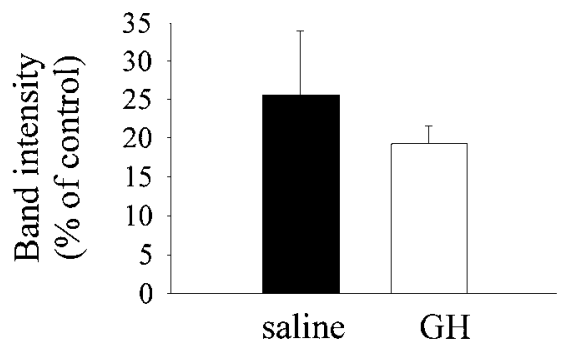

D

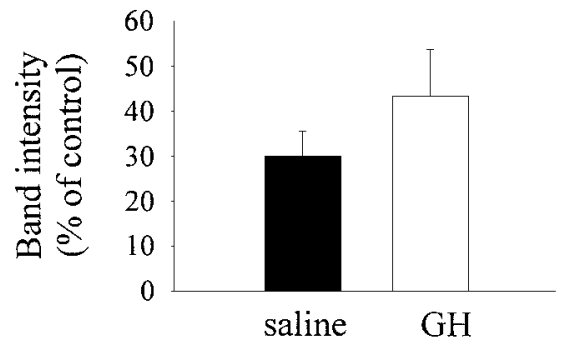

F

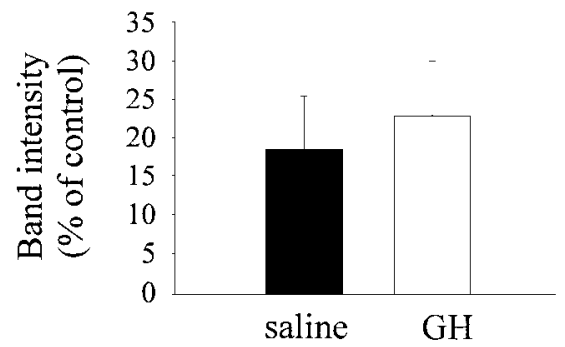

$\mathrm{H}$

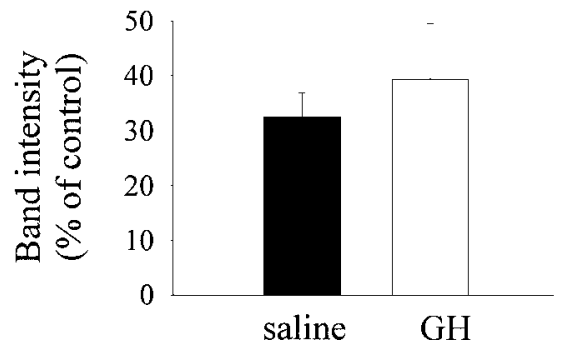


fragments was consistent with an RNase-sensitive region at the $3^{\prime}$ end of exon 1 . This required subcloning of the IGFBP-3 fragment in order to remove the $\mathrm{GC}$-rich region. The strategy used is outlined in Fig. 1. Digestion with EcoRI and PstI produced a 208-bp exon 1-specific fragment that encompassed the GC-rich region. Digestion with PstI and SalI produced a 256-bp fragment encoding the $3^{\prime}$ end of exon 1 and the $5^{\prime}$ end of exon 2, and digestion with SalI and SmaI produced a 131-bp fragment that encoded the remainder of exon 2 and the $5^{\prime}$ end of exon 3. These fragments were subcloned into pBluescript II $\mathrm{SK}+$ and linearised with EcoRI, PstI and SalI respectively, and used as templates for the production of antisense riboprobes for different regions of IGFBP-3.

The exon 1-specific riboprobe derived from plasmid p208BP3 was the correct size (278 nucleotides), but it failed to resolve protected fragments when hybridised with porcine liver RNA (data not shown). Using plasmid p256BP3 as a template for generating an exon $1 / 2$-specific riboprobe generated the expected 289-nucleotide probe. This RNA species, however, hybridised only partly to IGFBP-3 mRNA, yielding a protected fragment of 158 bases in length (data not shown). This analysis was not taken further.

An exon 2/3-specific riboprobe was generated with plasmid p131BP3. A 192-nucleotide riboprobe of the expected size protected a fragment of 139 bases in length when hybridised with porcine liver RNA. This result indicated that p131BP3 was suitable for generating a porcine IGFBP-3-specific riboprobe for use in an RNase protection assay to detect steady-state levels of IGFBP-3 mRNA.

The steady-state level of IGFBP-3 mRNA was measured in a number of tissues using this riboprobe and the results are illustrated in Figs 3 and 4. The data show that IGFBP-3 mRNA was significantly increased by $\mathrm{GH}$ treatment in liver $(P<0.03)$ and kidney $(P<0.05)$ (Fig. 3), but not in longissimus dorsi muscle, stomach and jejunum (Fig. 4).

\section{IGF-I mRNA detection}

IGF-I class $1 \mathrm{mRNA}$ was detected in all tissues examined, whereas IGF-I class 2 mRNA tran- scripts could only be detected in the liver. Additional IGF-I mRNA transcripts were also detected and are represented as a 147-nucleotide fragment. This fragment is generated from protection of exon 3 alone and represents non-class 1 and non-class 2 IGF-I mRNA transcripts (Weller et al. 1993). These exon 3 transcripts were also detected in all tissues examined. GH administration increased the level of IGF-I class $1(P<0 \cdot 02)$ and class 2 mRNA in liver $(P<0 \cdot 01)$ (Fig. 5). In kidney, longissimus dorsi muscle, stomach and jejunum, the IGF-I class 1 mRNA level was not changed by GH treatment (Fig. 6). Expression of the exon 3-only IGF-I transcript was also increased by $\mathrm{GH}$ treatment in liver (Fig. 5).

\section{DISCUSSION}

The effect of administration of exogenous GH to the pig is well established in terms of growth performance, improvement in food conversion efficiency and increased average daily weight gain (Etherton et al. 1986, Campbell et al. 1988, Klindt et al. 1992). In addition, plasma concentrations of IGF-I and IGFBP-3 are increased in pigs in response to growth hormone, consistent with their known actions as key components of the somatotrophic axis, co-ordinating the regulation of growth (Owens et al. 1990, Dunaiski et al. 1997). Expression of IGF-I mRNA is also increased in some porcine tissues in response to $\mathrm{GH}$, but there is no information on the expression of IGFBP-3 in pigs; most information on IGFBP-3 mRNA is derived from studies in the rat. IGFBP-3 is widely expressed, suggesting it has an important role in mediating the action of IGF peptides (Shimasaki et al. 1989), although there is little correlation between the expression of IGF-I and IGFBP-3 (Albiston \& Herington 1992). Mechanistically, this is of little relevance in the pig, which is more sensitive to $\mathrm{GH}$ administration than is the rat (Walton et al. 1995). The main objective of this study was to examine the effect of short-term GH administration on the steady-state levels of IGFBP-3 in a number of tissues in the pig, and compare it with the known expression patterns of IGF-I mRNA.

To accomplish this, we had to demonstrate the established effects of GH treatment. Accordingly,

FIGURE 6. Representative autoradiographs of RNase protection assays for IGF-I class 1 mRNA expression in kidney (A), muscle (C), stomach (E) and jejenum (G) of saline- and GH-treated pigs. Graphical representations of kidney (B), muscle (D), stomach (F) and jejenum (H) mRNA are shown. Band intensities were quantified using Image Quant software and are expressed as a percentage of the intensity obtained from hybridising the same RNA samples with an 18 S RNA probe. Results are expressed as the mean \pm s.E.M. $(n=5)$. 
the results showed that a 4-day treatment with $\mathrm{GH}$ at a dose of $70 \mu \mathrm{g} / \mathrm{kg} /$ day significantly increased average daily weight gain and improved feed efficiency, confirming the efficacy of the treatment and allowing mechanistic conclusions to be drawn from the study.

A porcine IGFBP-3 cDNA was first isolated from a liver and an ovarian cDNA library based on sequence information derived from the purification of a polypeptide from porcine follicular fluid, which was able to inhibit follicle-stimulating hormoneinduced oestradiol production by rat ovary granulosa cells (Shimasaki et al. 1990). A single mRNA species $(2.6 \mathrm{~kb})$ encoding porcine IGFBP-3 was detected in porcine ovary, testis, brain and liver by Northern blotting. The cDNA contained five exons, with the mature protein being encoded in the first four exons (Shimasaki et al. 1990). A plasmid derived from these original clones, containing the first three exons of porcine IGFBP-3, was kindly provided by Dr Shimasaki. Northern blotting has been the method of choice for the detection of IGFBP-3 mRNA in porcine tissues. Lee et al. (1993) measured IGFBP-3 mRNA using a human cDNA probe in liver, kidney, muscle and lung in samples taken from pigs throughout development. Although IGFBP-3 was identified in all tissues, there was a preponderance in the kidney. These authors noted that this was consistent with high expression of IGFBP-3 mRNA in the rat in one study (Albiston \& Herington 1992), but differed from the findings of a study of juvenile rats, which demonstrated greatest IGFBP-3 mRNA levels in the liver (Shimasaki et al. 1989). Other studies have detected IGFBP-3 mRNA in the porcine ovary primarily in the corpus luteum - sertoli cells and pancreas (Samaras et al. 1992, Besset et al. 1996, Gadsby et al. 1996, Zhou et al. 1996, Peng et al. 1998).

We attempted to quantify steady-state IGFBP-3 mRNA in a number of porcine tissues, using the more sensitive RNase protection assay. Initial experiments using the full-length insert from the plasmid pPBP3ES as a template to produce a riboprobe proved unsuccessful, as it generated two protected fragments of smaller size (250 and 238 bases), instead of the expected protected fragment of 595 bases. In order to correct this, the cDNA sequence containing the first three exons of porcine IGFBP-3 was digested with suitable restriction enzymes and subcloned to generate three probes complementary to different regions of porcine IGFBP-3 mRNA (see Fig. 1). However, a probe generated from $\mathrm{p} 208 \mathrm{BP} 3$ did not protect any RNA species in porcine liver. A second probe generated from $\mathrm{p} 256 \mathrm{BP} 3$ protected a fragment that was smaller than the expected 256 bases and was not used. An exon 2- and 3-specific probe of 192 bases was generated from $\mathrm{p} 131 \mathrm{BP} 3$. In a preliminary series of RNase protection assays, this IGFBP-3 probe gave rise to one protected fragment, 139 bases in length, that was specific to porcine IGFBP-3 mRNA, with a linear response over a range of RNA concentrations from 20 to $100 \mu \mathrm{g}$. This cDNA clone was used in all subsequent assays to detect changes in steady-state IGFBP-3 mRNA levels.

Using this riboprobe, we were able to demonstrate the expression of IGFBP-3 mRNA in all the tissues sampled, confirming the results of Lee et al. (1993). In addition, the results demonstrated that IGFBP-3 mRNA was increased by a short-term administration of $\mathrm{GH}$ in the liver and kidney, but not in other tissues. This suggests that the liver and kidney are the major source of the increase in circulating IGFBP-3 in the pig (Walton \& Etherton 1989), at least at the early stage of GH administration. Whether this is a direct effect of $\mathrm{GH}$ or a result of increased IGF-I is not clear. Type 1 IGF and $\mathrm{GH}$ receptors are present in both liver and kidney (Lee et al. 1993), therefore either hormone may stimulate IGFBP-3.

Further confirmation of the effects of $\mathrm{GH}$ in this study were provided by the increase in IGF-I class 1 and class 2 mRNA in response to GH treatment in porcine liver. These findings support previous studies in which GH administration increased IGF-I class 1 and class $2 \mathrm{mRNA}$ expression in liver (Brameld et al. 1996). In comparison, a decrease in hepatic IGF-I class 1 and class 2 mRNA is associated with a reduction in growth rate (Weller et al. 1994). Non-class 1 and non-class 2 IGF-I transcripts, as indicated by a 147-nucleotide protected fragment, were also sensitive to energy status (Weller et al. 1994), and increased with GH treatment in the present study.

IGF-I class 2 transcripts are more sensitive to changes in energy status than are class 1 transcripts, leading to a positive correlation between IGF-I class 2 gene expression and plasma IGF-I levels (Weller et al. 1994). In the present study, GH treatment resulted in a fourfold increase in liver IGF-I class 1 mRNA expression, whereas IGF-I class 2 transcripts were increased eightfold. This agrees with previous data suggesting that IGF-I class 2 transcripts are the primary source of endocrine-regulated IGF-I (Weller et al. 1994). The absence of IGF-I class 2 transcripts in muscle (Weller et al. 1994) and the absence of any detectable IGF-I class 2 transcripts in adipose tissue (Brameld et al. 1996), and in kidney, stomach and jejunum in our study confirms that the liver is the major source of endocrine-regulated IGF-I. 
Our study confirmed that the growth-promoting effect of $\mathrm{GH}$ on longissimus dorsi muscle is not associated with local expression of IGF-I. In longissimus dorsi, IGF-I expression was not regulated by GH or energy status (Grant et al. 1991, Coleman et al. 1994, Weller et al. 1994). In contrast, in semitendinosus muscle $\mathrm{GH}$ treatment increased IGF-I class 1 mRNA expression (Brameld et al. 1996).

It is clear that $\mathrm{GH}$ has an important role in IGF-I and IGFBP-3 gene expression. In the pig, the major source of endocrine-regulated IGF-I appears to be the liver, although GH also regulates IGF-I expression in adipose tissue, which may contribute to circulating concentrations (Wolverton et al. 1992). Whether this is due to an increase in IGF-I class 1 or class 2 expression has not been determined. In the liver, IGF-I class 2 transcripts are more responsive to endocrine growth control, although a subpopulation of transcripts termed non-class 1 and non-class 2 also appears to be regulated by GH. We have shown that IGFBP-3 gene expression in liver and kidney is also sensitive to exogenous GH. Whether this is a direct effect of $\mathrm{GH}$ or an indirect one through IGF-I is not clear. In the pig, IGF-I and IGFBP-3 mRNA expression are not affected by $\mathrm{GH}$ treatment in longissimus dorsi muscle, stomach or jejunum.

\section{ACKNOWLEDGEMENTS}

We would like to thank Simone Shaw, Robert Nason and Doug Kerton at the Victorian Institute of Animal Science for maintenance of the animals. Thanks are also due to the CRC for Tissue Growth and Repair for a scholarship to Vera Dunaiski.

\section{REFERENCES}

Albiston AL \& Herington AC 1992 Tissue distribution and regulation of insulin-like growth factor (IGF)-binding protein-3 messenger ribonucleic acid (mRNA) in the rat: comparison with IGF-I mRNA expression. Endocrinology $130497-502$.

Besset V, Le Magueresse-Battistoni B, Collette J \& Benahmed M 1996 Tumor necrosis factor alpha stimulates insulin-like growth factor binding protein 3 expression in cultured porcine Sertoli cells. Endocrinology 137 296-303.

Brameld JM, Atkinson JL, Sanders JC, Pell JM, Buttery PJ \& Gilmour RS 1996 Effects of growth hormone administration and dietary protein intake on insulin-like growth factor I and growth hormone receptor mRNA expression in porcine liver, skeletal muscle and adipose tissue. Fournal of Animal Science 74 1832-1841.

Campbell RG, Steele NC, Caperna TJ, McMurtry JP, Solomon MB \& Mitchell AB 1988 Interrelationships between energy intake and endogenous porcine growth hormone administration on the performance, body composition and protein and energy metabolism of growing pigs weighing 25 to 55 kilograms live-weight. Fournal of Animal Science 66 1643-1655.

Campbell RG, Steele NC, Caperna TJ, McMurtry JP, Solomon MB \& Mitchell AD 1989 Interrelationships between sex and exogenous growth hormone administration on performance, body composition and protein and fat accretion of growing pigs. Fournal of Animal Science 67 177-186.

Coleman ME \& Etherton TD 1991 Effects of exogenous porcine growth hormone on serum insulin-like growth factor binding proteins in growing pigs. Fournal of Endocrinology 128 175-180.

Coleman ME, Russell L \& Etherton TD 1994 Porcine somatotropin (pST) increases IGF-I mRNA abundance in liver and subcutaneous adipose tissue but not in skeletal muscle of growing pigs. Fournal of Animal Science 72 918-924.

Domenè H, Krishnamurthi K, Eshet R, Gilad I, Laron Z, Koch I, Stannard B, Cassorla F, Roberts CT Jr \& LeRoith D 1993 Growth hormone $(\mathrm{GH})$ stimulates insulin-like growth factor-I (IGF-I) and IGF-I-binding protein-3, but not $\mathrm{GH}$ receptor gene expression in livers of juvenile rats. Endocrinology 133 675-682.

Dunaiski V, Dunshea FR, Walton PE \& Goddard C 1997 Long [R3] insulin-like growth factor-I reduces growth, plasma growth hormone, IGF binding protein-3 and endogenous IGF-I concentrations in pigs. Fournal of Endocrinology 155 $559-565$.

Etherton TD, Wiggins JP, Chung CS, Evock CM, Rebhun JF \& Walton PE 1986 Stimulation of pig growth performance by porcine growth hormone and growth hormone releasing factor. Fournal of Animal Science 63 1389-1399.

Etherton TD, Wiggins JP, Evock CM, Chung CS, Rebhun JF, Walton PE \& Steele NC 1987 Stimulation of pig growth performance by porcine growth hormone: determination of the dose-response relationship. Fournal of Animal Science 64 433-443.

Gadsby JE, Lovdal JA, Samaras S, Barber JS \& Hammond JM 1996 Expression of the messenger ribonucleic acids for insulin-like growth factor-I and insulin-like growth factor binding proteins in porcine corpora lutea. Biology of Reproduction 54 339-346.

Grant AL, Helferich WG, Kramer SA, Merkel RA \& Bergen WG 1991 Administration of growth hormone to pigs alters the relative amount of insulin-like growth factor-I mRNA in liver and skeletal muscle. Fournal of Endocrinology 130 331-338.

Klindt J, Buonomo FC \& Yen JT 1992 Administration of porcine somatotropin by sustained release implant: growth and endocrine responses in genetically lean and obese barrows and gilts. Fournal of Animal Science 70 3721-3733.

Lee CY, Chung CS \& Simmen FA 1993 Ontogeny of the porcine insulin-like growth factor system. Molecular and Cellular Endocrinology 93 71-80.

Owens PC, Johnson RJ, Campbell RG \& Ballard FJ 1990 Growth hormone increases insulin-like growth factor-I (IGF-I) and decreases IGF-II in plasma of growing pigs. Fournal of Endocrinology 124 269-275.

Peng M, Abribat T, Calvo E, LeBel D, Palin MF, Bernatchez G, Morisset J \& Pelletier G 1998 Ontogeny of insulin-like growth factors (IGF), IGF binding proteins, IGF receptors, and growth hormone receptor mRNA levels in porcine pancreas. Fournal of Animal Science 76 1178-1188.

Samaras SE, Hagen DR, Shimasaki S, Ling N \& Hammond JM 1992 Expression of insulin-like growth factor-binding protein-2 and -3 messenger ribonucleic acid in the porcine 
ovary: localization and physiological changes. Endocrinology $1302739-2744$.

Saunders JC, Dickson MC, Pell JM \& Gilmour RS 1991 Expression of a growth hormone-responsive exon of the ovine insulin-like growth factor-I gene. Fournal of Molecular Endocrinology 7 233-240.

Shimasaki S, Koba A, Mercado M, Shimonaka M \& Ling N 1989 Complementary DNA structure of the high molecular weight rat insulin-like growth factor binding protein (IGF-BP3) and tissue distribution of its mRNA. Biochemical and Biophysical Research Communications 165 907-912.

Shimasaki S, Shimonaka M, Ui M, Inouye S, Shibata F \& Ling N 1990 Structural characterization of follicle stimulating hormone action inhibitor in porcine ovarian follicular fluid. Fournal of Biological Chemistry 265 2198-2202.

Walton PE \& Etherton TD 1989 Effects of porcine growth hormone and insulin-like growth factor-I (IGF-I) on immunoreactive IGF-binding protein concentration in pigs. Fournal of Endocrinology 120 153-160.

Walton PE, Dunshea FR \& Ballard FJ 1995 In vivo actions of IGF analogues with poor affinities for IGFBPs: metabolic and growth effects in pigs of different ages and GH responsiveness. Progress in Growth Factor Research 6 385-395.

Weller PA, Dickson MC, Huskisson NS, Dauncey MJ, Buttery PJ \& Gilmour RS 1993 The porcine insulin-like growth factor-I gene: characterisation and expression of alternate transcription sites. Fournal of Molecular Endocrinology 11 201-211.

Weller PA, Dauncey MJ, Bates PC, Bramfeld JM, Buttery PJ \& Gilmour RS 1994 Regulation of porcine insulin-like growth factor I and growth hormone receptor mRNA expression by energy status. American Fournal of Physiology 266 E776-E785.

Wolverton CK, Azain MJ, Duffy JY, White ME \& Ramsay TG 1992 Influence of somatotropin on lipid metabolism and IGF gene expression in porcine adipose tissue. American Fournal of Physiology 263 E637-E645.

Zhou J, Adesanya OO, Vatzias G, Hammond JM \& Bondy CA 1996 Selective expression of insulin-like growth factor system components during porcine ovary follicular selection. Endocrinology 137 4893-4901.

RECEIVED 21 October 1998 